\begin{tabular}{|c|c|c|c|}
\hline \multirow{3}{*}{$\begin{array}{r}\text { Case Reports in } \\
\text { Gastroenterology }\end{array}$} & \multicolumn{2}{|c|}{ Case Rep Gastroenterol 2019;13:364-368 } & \multirow[b]{2}{*}{$\begin{array}{l}\text { Karger } \\
\text { Open'access }\end{array}$} \\
\hline & $\begin{array}{l}\text { DOI: } 10.1159 / 000502683 \\
\text { Published online: September 5, } 2019\end{array}$ & $\begin{array}{l}\text { (c) } 2019 \text { The Author(s) } \\
\text { Published by S. Karger AG, Basel } \\
\text { www.karger.com/crg }\end{array}$ & \\
\hline & $\begin{array}{l}\text { This article is licensed under the } \\
\text { International License (CC BY-NC) } \\
\text { Usage and distribution for commercia }\end{array}$ & $\begin{array}{l}\text { mons Attribution-NonCommercial } 4.0 \\
\text { rger.com/Services/OpenAccessLicense). } \\
\text { quires written permission. }\end{array}$ & \\
\hline
\end{tabular}

\title{
Epiploic Appendagitis: An Often Misdiagnosed Cause of Acute Abdomen
}

\author{
Vishnu Charan Suresh Kumar ${ }^{a, b} \quad$ Kishore Kumar Mani $^{c}$ \\ Hisham Alwakkaab James Shina ${ }^{b}$ \\ aDepartment of Medicine, State University of New York Upstate Medical University, \\ Syracuse, NY, USA; ${ }^{b}$ Department of Medicine, Western Reserve Health Education/ \\ NEOMED, Warren, OH, USA; 'S.R.M. Medical College Hospital and Research Centre, \\ Kattankulathur, India
}

\section{Keywords}

Epiploic appendagitis · Acute abdomen · Obesity · Diverticulitis · Appendicitis

\begin{abstract}
Epiploic appendages are peritoneal structures that arise from the outer serosal surface of the bowel wall towards the peritoneal pouch. They are filled with adipose tissue and contain a vascular stalk. Epiploic appendagitis is a rare cause of acute lower abdominal pain. It most commonly results from torsion and inflammation of the epiploic appendages, and its clinical features mimic acute diverticulitis or acute appendicitis resulting in being often misdiagnosed as diverticulitis or appendicitis. This frequently leads to unnecessary hospitalization, antibiotic administration, and unwarranted surgeries. Epiploic appendagitis is usually diagnosed with CT imaging, and the classic CT findings include: (i) fat-density ovoid lesion (hyperattenuating ring sign), (ii) mild bowel wall thickening, and (iii) a central high-attenuation focus within the fatty lesion (central dot sign). It is treated conservatively, and symptoms typically resolve in a few days. Therefore, epiploic appendagitis should be considered as one of the differential diagnosis for acute lower abdominal pain and prompt diagnosis of epiploic appendagitis can avoid unnecessary hospitalization and surgical intervention. In this case report, we discuss a 72-yearold woman who presented with a 2-day history of acute left lower abdominal pain.
\end{abstract}




\section{Case Reports in Gastroenterology}

Case Rep Gastroenterol 2019;13:364-368

DOI: $10.1159 / 000502683$

(c) 2019 The Author(s). Published by S. Karger AG, Basel www.karger.com/crg

Suresh Kumar et al.: Epiploic Appendagitis: An Often Misdiagnosed Cause of Acute Abdomen

\section{Introduction}

Epiploic appendagitis is an uncommon clinical entity that is caused by ischemic infarction of an epiploic appendage due to torsion or thrombosis of the central draining vein [1]. The clinical manifestations include acute abdominal pain, most commonly in the left lower quadrant. It is often misdiagnosed as acute diverticulitis or appendicitis. Most patients are afebrile and have a normal leukocyte count [2]. Due to the lack of specific clinical features, it is typically diagnosed with a contrast-enhanced CT scan of the abdomen. Here, we report a case of a 72year-old lady who presented with acute left lower quadrant abdominal pain. The purpose of this case report is to raise awareness of a rare clinical entity with its characteristic imaging findings. This is very important to avoid hospitalization costs and undue morbidity and mortality associated with surgical procedures.

\section{Case Report}

A 72-year-old lady with a past medical history of supraventricular tachycardia, hypertension, and dyslipidemia presented to the emergency department with complaints of localized left lower abdominal pain. The pain was sudden in the onset and progressively worsened to an intensity of $8 / 10$ in the last 2 days, without any relieving or aggravating factors. No history of fever, chills, nausea, vomiting, anorexia, urinary symptoms, or change in bowel habits was reported. No previous history of appendicitis, diverticulitis, or similar complaints was found.

On examination, the patient was not in acute distress. She was afebrile, vital signs were within normal limits, and abdominal examination was positive for localized tenderness on palpation in the left lower quadrant. The rest of the physical examination and laboratory studies were unremarkable.

Contrast-enhanced CT of the abdomen and pelvis showed acute uncomplicated diverticulitis. The patient was admitted to the inpatient service and was started on intravenous antibiotics and analgesics. Gastroenterology was consulted for continuity of care and interval colonoscopy as an outpatient after 6-8 weeks.

On day 2 of hospitalization, when the inpatient medicine team reviewed the CT, there was a $20 \times 10 \times 10 \mathrm{~mm}$ fat-density ovoid lesion with a hyperattenuated center abutting the anterior wall of the proximal sigmoid colon with, mild thickening of the adjacent colonic wall and stranding of the adjacent fat (Fig. 1). Coronal section on CT scan showed the ovoid lesion again (Fig. 2). The constellation of these radiographic findings led to the diagnosis of acute epiploic appendagitis.

The antibiotics were discontinued immediately, and the patient was monitored for $24 \mathrm{~h}$ with pain control. The patient had complete resolution of her symptoms within $48 \mathrm{~h}$ of her initial presentation and was discharged home. There was no recurrence of symptoms during the 9 months of follow-up.

\section{Discussion}

Epiploic appendages are fat-filled, serosa-covered pedunculated peritoneal structures extending into the peritoneal pouch from the outer bowel wall [1]. Vesalius first described their anatomy in $1543[3,4]$. They range from 0.5 to $5 \mathrm{~cm}$ in the largest dimension and are positioned in two separate longitudinal lines along the serosal surface of the colon. The 


\section{Case Reports in Gastroenterology}

Case Rep Gastroenterol 2019;13:364-368

DOI: $10.1159 / 000502683$

c) 2019 The Author(s). Published by S. Karger AG, Basel www.karger.com/crg

Suresh Kumar et al.: Epiploic Appendagitis: An Often Misdiagnosed Cause of Acute Abdomen

appendages contain branches of a circular end-artery and a central draining vein. Although they can occur anywhere in the colon, they are larger in size and more in number on the sigmoid and transverse colon walls [2]. Some suggest that the appendages function as a blood reservoir, provide cushioning and immunity, and help in colonic absorption. However, the exact function of the appendages is still unknown [5, 6]. The inflammation of the epiploic appendages is known as epiploic appendagitis. This term was coined by Lynn and colleagues [7] in 1956. The incidence is reported to be 8.8 per million people every year [8]. Epiploic appendagitis is reported to be associated with obesity, hernia, exercise injury, and most often occurs in males during their 3rd to 5 th decade of life $[6,9,10]$. The pathophysiology of epiploic appendagitis was first described by Hunt [11] in 1919. It is most commonly caused by torsion of the epiploic appendages leading to obstruction of its vascular supply followed by necrosis. However, it can also occur due to embolic or thrombotic causes $[2,12]$. As there is inadequate protection from the momentum or the surrounding appendages, a sudden vascular obstruction due to torsion may lead to rapid necrosis of the pedicle resulting in the release of the appendage into the peritoneal cavity as a free body encysted by its peritoneal coat [11]. In a study by Thomas et al. [13], 208 cases of epiploic appendagitis were reviewed and they found that $73 \%$ of cases were due to torsion and inflammation, $18 \%$ due to hernia incarceration, $8 \%$ due to intestinal obstruction, and $<1 \%$ due to intraperitoneal loose body $[2,13]$. In a recent 7 year retrospective study, epiploic appendagitis patients were found to have $60 \%$ more abdominal adipose volume, $117 \%$ more visceral adipose area, and 35\% more subcutaneous adipose area than the control group [9]. Epiploic appendagitis presents with sudden onset of localized left or right lower quadrant abdominal pain that often mimics appendicitis or diverticulitis and aggravates on coughing and abdominal stretching. Rarely, the patient might have nausea and vomiting $[2,3,14,15]$. Retrospective studies conducted in the Netherlands and Argentina with 49 and 73 cases, respectively, found that the most common presentation was left lower quadrant pain (69-89\%), right lower quadrant pain (8-16\%), and pain at other locations including right and left upper quadrant $(1.5-3 \%)[16,17]$. The white blood count is generally not elevated, and there are no diagnostic laboratory values characteristic of epiploic appendagitis [18]. Given the lack of typical symptoms and signs, it is often misdiagnosed as either appendicitis or diverticulitis depending on the location and treated accordingly. It is often diagnosed by abdominal CT imaging, and before the widespread use of CT imaging, only $2.5 \%$ were clinically diagnosed accurately before surgery $[2,13]$. Normal epiploic appendages are not evident on CT imaging, but they can be detected when they are inflamed or outlined by ascites. The key features on CT imaging include fat-density ovoid lesion also known as hyperattenuating ring sign, mild bowel wall thickening, and a central high-attenuation focus within the fatty lesion which in recent studies has been described as the central dot sign [1921]. Epiploic appendagitis is usually self-limiting and can be treated, and $92 \%$ of the cases were successfully treated as an outpatient with anti-inflammatory drugs $[17,22]$. In a study by Rao et al. [23], 660 CT scans performed for suspected diverticulitis or appendicitis and hospital costs were reviewed. Among the 660 scans, 11 scans (2\%) showed features of epiploic appendagitis, out of which 4 were originally reported as appendagitis, 6 were misdiagnosed as diverticulitis, and 1 was misdiagnosed as appendicitis. All the misdiagnosed patients were hospitalized, while 6 of them received antibiotics, and the average medical expense rose up to USD 4,117 per patient. On the other hand, none of the originally correctly diagnosed patients received antibiotics while 1 patient was hospitalized for a day. This led to an average medical cost of USD 1,205 per patient [23]. In another study involving 73 cases of epiploic appendagitis, in $49 \%$ of the patients, a surgical consult was called [17]. Awareness of this entity amongst clinicians and identification of typical CT findings by radiologists upon 
initial presentation would help reduce unnecessary antibiotic use, diagnostic testing, unwanted surgical consults, and in some instances unwarranted surgery. Most importantly, it would reduce patient costs and avoid putting the patient through a stressful situation. Further studies are needed to throw light on the exact pathophysiology and etiologies of epiploic appendagitis.

\section{Statement of Ethics}

The patient gave her informed consent before publication.

\section{Disclosure Statement}

The authors have no conflicts of interest.

\section{Funding Sources}

This study did not receive any funding support.

\section{References}

1 Rodríguez Gandía MÁ, Moreira Vicente V, Gallego Rivera I, Rivero Fernández M, Garrido Gómez E. Epiploic appendicitis:the other appendicitis. Gastroenterol Hepatol. 2008;31(2):98-103.

2 Singh AK, Gervais DA, Hahn PF, Sagar P, Mueller PR, Novelline RA. Acute epiploic appendagitis and its mimics. Radiographics. 2005 Nov-Dec;25(6):1521-34.

3 Sand M, Gelos M, Bechara FG, Sand D, Wiese TH, Steinstraesser L, et al. Epiploic appendagitis-clinical characteristics of an uncommon surgical diagnosis. BMC Surg. 2007 Jul;7(1):11.

4 Vesalius A. De humanis corporis fabrica libri septem. Basel: Ex officina Joannis Oporini; 1543.

5 Marinis TP, Cheek JH. Primary Inflammation of the Appendices Epiploicae : With Review of the Literature and Report of Six Additional Cases. Ann Surg. 1949 Apr;129(4):533-7.

6 Patel H, Abdelbaki A, Steenbergen P, Chanana C, Li S. Know the name: acute epiploic appendagitis-CT findings and review of literature. AME Case Rep. 2018 Mar;2:8.

7 Dockerty MB, Lynn TE, Waugh JM. A clinicopathologic study of the epiploic appendages. Surg Gynecol Obstet. 1956 Oct;103(4):423-33.

8 de Brito P, Gomez MA, Besson M, Scotto B, Alison D, Huten N. Frequency and epide-miology of primary epiploic appendagitis on CT in adults with abdominal pain. J Radiol. 2008 Feb;89(2):235-43.

9 Nugent JP, Ouellette HA, O'Leary DP, Khosa F, Nicolaou S, McLaughlin PD. Epiploic appendagitis: 7-year experience and relationship with visceral obesity. Abdom Radiol (NY). 2018 Jul;43(7):1552-7.

10 Carmichael DH, Organ CH Jr. Epiploic disorders. Conditions of the epiploic appendages. Arch Surg. 1985 Oct;120(10):1167-72.

11 Hunt VC. Torsion of Appendices Epiploicae [PhD thesis]. University of Minnesota Digital Conservancy; 1918.

12 Ross JA. Vascular loops in the appendices epiploicae; their anatomy and surgical significance, with a review of the surgical pathology of appendices epiploicae. Br J Surg. 1950 Apr;37(148):464-6.

13 Thomas JH, Rosato FE, Patterson LT. Epiploic appendagitis. Surg Gynecol Obstet. 1974 Jan;138(1):23-5.

14 Almeida AT, Melão L, Viamonte B, Cunha R, Pereira JM. Epiploic appendagitis: an entity frequently unknown to clinicians—diagnostic imaging, pitfalls, and look-alikes. AJR Am J Roentgenol. 2009 Nov;193(5):1243-51.

15 Sandrasegaran K, Maglinte DD, Rajesh A, Akisik FM. Primary epiploic appendagitis: CT diagnosis. Emerg Radiol. 2004 Aug;11(1):9-14.

16 van Breda Vriesman AC, de Mol van Otterloo JC, Puylaert JB. [Epiploic appendagitis: an underestimated selflimiting acute abdominal condition]. Ned Tijdschr Geneeskd. 2003 Jun;147(23):1113-8.

17 Vázquez GM, Manzotti ME, Alessandrini G, Lemos S, Perret MC, Catalano HN. [Primary epiploic appendagitis: clinical features in 73 cases]. Medicina (B Aires). 2014;74(6):448-50. 


\section{Case Reports in Gastroenterology}

\begin{tabular}{l|l}
\hline Case Rep Gastroenterol 2019;13:364-368 \\
\hline DOI: 10.1159/000502683 & $\begin{array}{l}\text { @ 2019 The Author(s). Published by S. Karger AG, Basel } \\
\text { www.karger.com/crg }\end{array}$ \\
\hline
\end{tabular}

Suresh Kumar et al.: Epiploic Appendagitis: An Often Misdiagnosed Cause of Acute Abdomen

18 Legome EL, Murray RE, Belton AL, Rao PM, Novelline RA. Epiploic appendagitis: the emergency department presentation. J Emerg Med. ISSN: 2002;22(1):9-13.

19 Giambelluca D, Cannella R, Caruana G, Salvaggio L, Grassedonio E, Galia M, et al. CT imaging findings of epiploic appendagitis: an unusual cause of abdominal pain. Insights Imaging. 2019 Feb;10(1):26.

20 Nejadhamzeeigilani H. The central dot sign of epiploic appendagitis. Abdom Radiol (NY). 2019 Feb;44(2):802-3.

21 Giambelluca D, Dimarco M, Vaccaro Notte MR, Lo Re G, Midiri M. The "central dot sign" in acute epiploic appendagitis. Abdom Radiol (NY). 2019 Apr;44(4):1606-7.

22 Schnedl WJ, Krause R, Tafeit E, Tillich M, Lipp RW, Wallner-Liebmann SJ. Insights into epiploic appendagitis. Nat Rev Gastroenterol Hepatol. 2011 Jan;8(1):45-9.

23 Rao PM, Rhea JT, Wittenberg J, Warshaw AL. Misdiagnosis of primary epiploic appendagitis. Am J Surg. 1998 Jul;176(1):81-5.

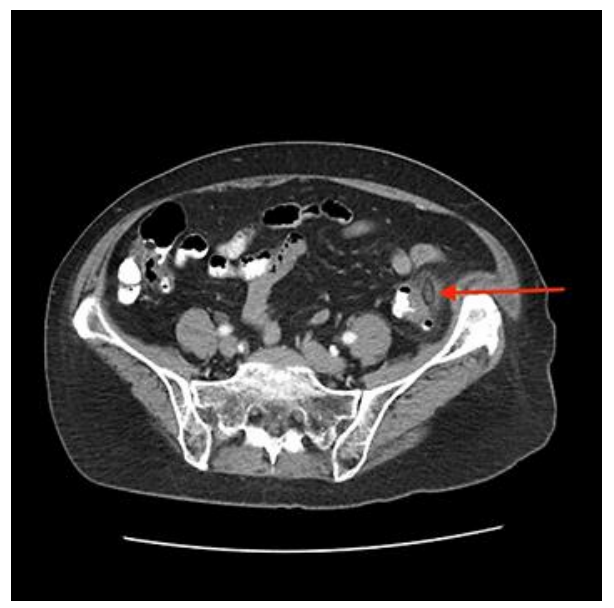

Fig. 1. A $20 \times 10 \times 10 \mathrm{~mm}$ fat-density ovoid lesion with a hyperattenuated center (central dot sign) abutting the anterior wall of the proximal sigmoid colon (red arrow) is seen on the CT scan of the abdomen and pelvis.

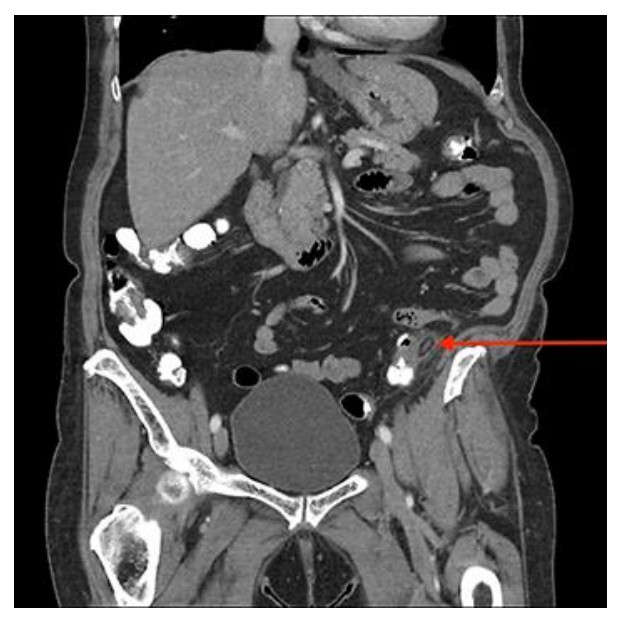

Fig. 2. The coronal section on the CT scan shows the ovoid lesion (red arrow). 